\title{
İşletmelerin Devlet Teşviklerine Eğilimlerinin Ölçülmesi ve Muhasebe Meslek Mensuplarının Katkıları
}

\section{Measuring the Trends of Businesses to Government Incentives and Contribution of Professional Accountants}

Meral GÜNDÜZ1 ${ }^{1}$ Ahmet COȘKUN ${ }^{2}$

\begin{abstract}
$\ddot{O ̈ z}$
Amaç: Bu çalışmanın amacı Uşak ilinde faaliyet gösteren şirketlerin devlet teşviklerinden ne ölçüde yararlandıklarını ve bu teşviklerden yararlanmalarında muhasebe meslek mensubunun katkısını ölçmektir.

Tasarım/Yöntem: Araştırmada Uşak'ta faaliyet gösteren 168 şirkete yüz yüze anket yapılmıştır. Elde edilen veriler Frekans Analizi, Faktör Analizi, Varyans Analizi, Lojistik Regresyon ve KiKare Testleri yapılarak değerlendirilmiștir.
\end{abstract}

Bulgular: Çalışmanın sonucunda anket yapılan şirketlerin \%57'si devlet teşviklerinden yararlandığ 1 ve devlet teşviklerinden yararlanan şirketlerin \%36'sı bu konuda serbest muhasebeci mali müşavirlerinden destek aldıkları tespit edilmiş̧ir. Ayrıca mali müşavirlerinin devlet teşviklerine ilişkin verdiği bu destek sonucunda şirketlerin ihracatlarının, satışlarının, üretimlerinin ve kârlılıklarının arttı̆ğ belirlenmiștir.

Sinırlılıklar: Örneklemin sadece Uşak’ta faaliyet gösteren şirketlerden oluşması araştırmanın sınırlılıklarıdır.

Özgünlük/Değer: Literatürde devlet teşviklerine ilişkin birçok çalışma yapılmasına rağmen, sirketlerin devlet teșviklerinden yararlanmalarında ve devlet teşviklerinden elde ettikleri faydalarda serbest muhasebeci mali müşavirlerin etkisinin ölçülmesi bakımından daha önce benzer bir çalıșmanın yapılmamış olması araştırmanın özgün değerini oluşturmaktadır. $\mathrm{Bu}$ bakımdan muhasebe meslek mensuplarına ilişkin bundan sonra yapılacak calışmalara da yol gösterici olacaktır.

Anahtar Kelimeler: Devlet Teşviki, Muhasebe Meslek Mensubu, Muhasebe, İșletme

\begin{abstract}
Purpose: The aim of this study is to measure the extent to which companies operating in Uşak benefit from government incentives and the contribution of professional accountant to these incentives.

Design/Methodology: In the research, a face-to-face questionnaire was conducted with 168 companies operating in Uşak. The data obtained were evaluated by performing Frequency Analysis, Factor Analysis, Variance Analysis, Logistic Regression and Chi-Square Tests.

Findings: As a result of the study, it was determined that $57 \%$ of the companies surveyed benefited from state incentives and $36 \%$ of the companies benefiting from the government incentives received support from professional accountants. In addition, as a result of the support given by their financial advisors for government incentives, it was determined that the exports, sales, production and profitability of the companies increased.

Limitations: The limitations of the study are that the sample consists of companies operating only in Ușak

Originality/Value: Although there are many studies on government incentives in the literature, the fact that a similar study has not been carried out before in terms of measuring the effect of professional accountants on the benefits of companies benefiting from government incentives and government incentives constitutes the original value of the study. In this respect, it will be a guide for the future studies regarding accounting professionals.
\end{abstract}

Keywords: Government Incentives, Accounting Professionals, Accounting, Business

1 Dr. Öğr. Üyesi, Uşak Üniversitesi, Uygulamalı Bilimler Fakültesi, Muhasebe ve Finans Yönetimi Bölümü, meral.gunduz@usak.edu.tr, ORCID: 0000-0002-9255-091X

2 Dr. Öğr. Üyesi, Uşak Üniversitesi, Uygulamalı Bilimler Fakültesi, Finans ve Bankacılık Bölümü, ahmet.coskun@usak.edu.tr, ORCID: 0000-0002-3223-8676 


\section{GíRiş}

Günümüzde gelişmekte olan ülkeler kalkınmanın sağlanması, gelişmiş ülkeler ise bölgesel farklılıkların azaltılması ya da ortadan kaldırılması amacıyla işletmelere bir takım yardımlar yapmakta ve teşvikler sağlamaktadır. Dünya genelinde ise yeni yatırımların sağlanması, üretimin ve istihdamın artırılması, sektörel iyileşmelerin desteklenmesi ve geliştirilmesi, toplumsal refahın artırılması için bütün devletler işletmelere parasal ve parasal olmayan yardım, destek ve özendirmeler yapmaktadırlar. $\mathrm{Bu}$ desteklere genel anlamda devlet teşvikleri denilmektedir (Altınkaynak \& Doğan, 2020).

Teşvik kavramı, ülkelerin kalkınma stratejilerine ve mevcut sosyo-ekonomik ve toplumsal yapılarına bağlı olarak belirli yatırımların yapılmasını özendirmek amacıyla kamu tarafından sağlanan nakdi ve nakdi olmayan destekler olarak tanımlanabilir (Özer, 2015). Teşvik ifadesi yerine "sübvansiyon", "mali yardım", "prim”, "ucuz kredi", "ayni yardım” gibi ifadeler de kullanılmaktadır (Y1ldiz vd., 2012).

Türkiye'de devlet yardımlarına ilişkin 16 Temmuz 2009 tarih ve 27290 sayılı "Yatırımlarda Devlet Yardımları Hakkında Bakanlar Kurulu Kararı" ile devlet teşvikleri düzenlenmiştir. Yııllar içerisinde birçok kez bu kararda değişiklik yapılmasına ilişkin kararlar yayımlanmıştır. Bu kararın amacı katma değeri yüksek yeni yatırımları teşvik etmek, üretim ve istihdamı artırmak, yatırımların devamlılığını sağlamaktır. Ayrıca bölgesel kalkınmayı sağlamak, daha büyük ve yabancı yatırımları özendirmek, araştırma-geliştirme çalışmalarını artırmak da bu kararın amaçları arasındadır (Tekşen, 2010). Devlet yardımlarına ilişkin en son 21 Ağustos 2020 tarih ve 31220 sayılı "Yatırımlarda Devlet Yardımları Hakkında Kararda Değişiklik Yapılmasına İlişkin Karar" Resmi Gazetede yayımlanmıştır. $\mathrm{Bu}$ kararda illerin hangi teşvik bölgelerinde olduğu belirlenmiş, bölgesel desteklerden faydalanabilecek sektörler, bölgeler itibariyle asgari yatırım tutarları ve kapasiteleri, teşviklerden yararlanacak yatırım konuları açıklanmıştır.

Türkiye'de 21 Ağustos 2020 tarih ve 31220 sayılı "Yatırımlarda Devlet Yardımları Hakkında Kararda Değişiklik Yapılmasına İlişkin Karar" da 6 teşvik bölgesi belirlenmiştir. Bölgelerin özelliklerine göre yararlanılan devlet teşvikleri her bölge için ayrı ayrı sayılmıştır. Kararda belirtilen genel devlet teşvikleri Katma Değer Vergisi İstisnası ve Gümrük Vergisi Muafiyetidir. Vergi İndirimi, Sigorta Primi İşveren Hissesi Desteği, Sigorta Primi Desteği, Gelir Vergisi Stopaji Desteği, Faiz Veya Kar Payı Desteği, Yatırım Yeri Desteği, Katma Değer Vergisi İadesi ise bölgesel teşviklerdir. Tablo 1.'de teşvik bölgeleri ve yararlanılabilecek teşvikler gösterilmiştir.

Tablo 1: Teşvik Bölgeleri ve Teşvik Destek Unsurları

\begin{tabular}{|c|c|c|c|c|c|c|}
\hline \multirow{2}{*}{$\begin{array}{l}\text { Yatırım Teşvik Belgesi } \\
\text { Teşvik Bölgeleri }\end{array}$} & \multicolumn{6}{|c|}{ Bölgesel Teșvik Destek Unsurları } \\
\hline & 1.Bölge & 2.Bölge & 3.Bölge & 4.Bölge & 5.Bölge & 6.Bölge \\
\hline KDV Muafiyeti & Var & Var & Var & Var & Var & Var \\
\hline Gümrük Muafiyeti & Var & Var & Var & Var & Var & Var \\
\hline Vergi Muafiyeti (\%) & 15 & 20 & 25 & 30 & 40 & 50 \\
\hline SGK İşveren Prim Muafiyeti & $2 \mathrm{y} 1 \mathrm{l}$ & 3 y1l & 5 y1l & $6 \mathrm{y} 1 \mathrm{l}$ & $7 \mathrm{y} 1 \mathrm{l}$ & $10 \mathrm{y} 11$ \\
\hline Yatırım Yeri Tahsisi & Var & Var & Var & Var & Var & Var \\
\hline Faiz veya Kar Payı Desteği & Yok & Yok & 3 puan & 4 puan & 5 puan & 7 puan \\
\hline (TL/Döviz) & Yok & Yok & 1 puan & 1 puan & 2 puan & 2 puan \\
\hline Yapı Harçları Muafiyeti & Var & Var & Var & Var & Var & Var \\
\hline Emlak Vergisi Muafiyeti & Var & Var & Var & Var & Var & Var \\
\hline Damga Vergisi Muafiyeti & Var & Var & Var & Var & Var & Var \\
\hline
\end{tabular}

Kaynak: https://dengemusavirlik.com/2013-yatirim-tesvik-sistemi.htm

İşletmeler, televizyon, radyo, gazete, dergi ve internet gibi iletişim kanalları, diğer işletmeler, ticaret ve sanayi odaları aracılığıyla devlet teşvikleri hakkında bilgi sahibi olurlar. Devlet teşviklerine ilişkin bilgi aldıkları taraflardan birisi de muhasebe meslek mensubu olan serbest muhasebeci mali müşavirleridir. Serbest muhasebeci mali müşavirlerin çalışma konularından birisi de "gerçek ve tüzel kişilere ait teşebbüs ve işletmelerin, muhasebe sistemlerini kurmak, geliştirmek, işletmecilik, muhasebe, finans, mali mevzuat ve bunların uygulamaları ile ilgili işlerini düzenlemek veya bu konularda müşavirliklerini yapmak"tır (TURMOB, 2021). Dolayısıyla işletmelerin devlet teşvikleri hakkında bilgi sahibi olması, teşviklerden yararlanması ve yatırımlarını sürdürmesinde mali müşavirlerin önemi büyüktür. 
Bu çalışmanın amacı, Yatırım Teşvik Uygulamalarında 3. Bölgede yer alan Uşak'ta faaliyet gösteren şirketlerin devlet teşviklerinden yararlanma eğilimlerinin saptanması ve söz konusu şirketlerin devlet teşviklerine yönelmelerinde serbest muhasebeci mali müşavirlerinin katkısını ölçmektir. Çalışmada devlet teşviklerine ilişkin teorik bilgi verilirken, Uşak'ta faaliyet gösteren şirketlere yapılan anket sonuçları Frekans Analizi, Faktör Analizi, Varyans Analizi, Lojistik Regresyon ve Ki-Kare Testleri yapılarak değerlendirilecektir.

$\mathrm{Bu}$ çalışma, literâtürde devlet teşviklerine ilişkin birçok çalışma yapılmasına rağmen, şirketlerin devlet teşviklerinden yararlanmalarında ve devlet teşviklerinden elde ettikleri faydalarda serbest muhasebeci mali müşavirlerin etkisinin ölçülmesi bakımından daha önce benzer bir çalışmanın yapılmamış olması nedeniyle son derece önemlidir. Bu bakımdan muhasebe meslek mensuplarına ilişkin bundan sonra yapılacak çalışmalara da yol gösterici olacaktır.

\section{LITERATÜR TARAMASI}

Literatür taramasında devlet teşviklerine ilişkin birçok çalışmaya rastlanmıştır. Muhasebe açısından özellikle muhasebe standartlarına göre devlet teşiklerinin muhasbeşleştirilmesine ve vergi uygulamaları açısından değerlendirilmesine ilişkin çalışmalara yer verilmiştir.

Tekşen (2010), TMS 20 Standardındaki devlet teşvikleri ile Türkiye'de yeni teşvik sisteminde yatırıma sağlanan desteklerin muhasebe ve vergi açısından incelenmesini yapmıştır. TMS 20 standardına göre yatırımlara sağlanan devlet teşviklerinin muhasebeleştirilmesine ilişkin örnekler vermiştir.

Akdoğan (2011), Türkiye'de uygulanan devlet teşvikleri ve devlet yardımlarının, uluslararası muhasebe standartları çerçevesinde analizini yapmıştır. Çalışmada, devlet teşviklerinin muhasebe standartlarına göre uygulama etkileri gösterilmiş ve Türkiye'de devlet teşviklerinin muhasebeleştirme ilkeleri çerçevesinde her teşvik unsuru için ayrı olarak değerlendirilmesi gerektiği vurgulanmıştır.

Yıldız ve diğerleri (2012), sanayi işletmelerine verilen devlet teşvikleri ve bu teşviklerin muhasebe standartları doğrultusunda muhasebeleştirilmesine ilişkin yaptıkları çalışmada gelir ve sermaye yaklaşımına göre muhasebeleştirilme farklılıklarını ortaya koymaya çalışmışlardır.

Özer (2015), hazırladığı yüksek lisans tez çalışmasında Mardin ilindeki turizm teşviklerini incelemiş ve TMS 20 muhasebe standardına göre teşviklerin muhasebeleştirilmesini ele almıştır. Çalışmanın sonucunda Mardin ilinin devlet teşviklerinden yeterince yararlanmadığı tespit edilmiştir.

Yakupçebioğlu (2016), "kentsel dönüşüm kapsamındaki inşaatlara ilişkin verilen devlet yardımları, teşvikleri, muafiyetler, vergi ve muhasebe uygulamalarına ilişkin bir çalışma yapmıştır.

Özbek (2017), hazır giyim işletmelerinde devlet teşvikleri üzerine bir çalışma yapmıştır. Bu çalışmada hazır giyim işletmelerinin \%42'sinin devlet teşviklerinden yaralandığı ve yararlananların \%75'inin teşvikten yararlanmaya devam edeceğini tespit etmiştir. Devlet teşviklerinin hazır giyim işletmelerinde üretim miktarı, ürün çeşitliliğgi, ihracat, satış ve karlılık oranlarını olumlu etkilediğini ifade etmiştir.

Sarıhan ve diğerleri (2017), devlet teşviklerinin İstanbul'da ihracat yapan firmaların performansına etkilerini incelemek amacıyla bir çalışma yapmışlardır. Çalışmanın sonucunda yararlanılan teşviklerin firmalara küresel rekabet ve stratejik pozisyon avantajı sağladığını ifade etmişlerdir.

Zhang ve Guan (2018), hükümetin mali teşviklerinin firmaların yenilikçi performansı üzerindeki zamanla değişen etkilerine odaklanarak, mevcut teorik araştırmaları ilerletmek amacıyla bir çalışma yapmışlardır. Çalışmanın sonucunda doğrudan devlet teşviklerinin kısa vadede firmaları desteklediğini, ancak uzun vadeli inovasyon performanslarında onları engellediği kanaatine varmışlardır.

Temelli (2019), tarımsal devlet teşvikleri ile ilgili bir çalışma yapmış ve tarımsal teşviklere ilişkin bilgi verdikten sonra tarımsal faaliyetlere ilişkin devlet teşviklerinin Türkiye Muhasebe Standartları'na göre muhasebeleştirilmesini sayısal örnekler yardımıyla açıklamıştır. 
Altınkaynak ve Doğan (2020), turizm sektöründe Türkiye'deki finansal raporlama çerçevelerine göre devlet teşviklerinin karşılaştırmalı analizini yapmışlardır. Çalışmanın sonucunda devlet teşviklerinin muhasebeleştirilmesinde, her sektör için verilen teşviklerin o sektöre uygun tek bir kayıt yaklaşımının uygulanmasını önermişlerdir.

\section{ARAŞTIRMA}

\subsection{Araştırmanın Kapsamı ve Amacı}

Yapılan araştırmada devlet teşvikleri açısından 3. Bölgede yer alan Uşak ilinde faaliyet gösteren şirketlerin devlet teşviklerinden yararlanıp yararlanmadıklarının tespit edilmesi ve devlet teşviklerinden yararlanılmasında mali müşavirlerinin katkısının ölçülmesi amaçlanmıştır. Bu amaçla Uşak ilinde organize ve karma sanayi bölgesinde faaliyet gösteren 168 şirkete yüz yüze anket uygulanmıştır. Kullanılan anket yöntemi için Uşak Üniversitesi Etik Kurulu'ndan 09/03/2021 tarihli ve 03 nolu toplantısında 2021-43 sıra sayılı kararı ile izin alınmıştır. Anket sonuçlarına Frekans Analizi, Faktör Analizi, Varyans Analizi, Lojistik Regresyon ve Ki-Kare Testi yapılmıştır.

Çalışmanın ilk bölümünde frekans analizi sonuçları değerlendirilmiştir. Şirketlerin sektörü, faaliyet alanları, çalışan sayılarına ilişkin genel bilgiler değerlendirilirken, devlet teşviklerine ilişkin eğilimleri saptanmaya çalışılmıştır. Çalışmanın ikinci bölümünde ise şirketlerin devlet teşviklerinden yararlanmasında ve sürdürülmesinde şirket mali müşavirlerinin katkısının olup olmadığı test edilmiştir. Son bölümde de mali müşavirin devlet teşvikleri konusunda bilgili olmasıyla şirket satışları, ihracatı, üretimi ve karlılı̆̆ı arasındaki ilişki analiz edilmiştir.

\subsection{Araştırmanın Bulguları}

Anket sonuçlarına frekans analizi uygulanmıştır. Analizin sonucunda aşağıdaki değerlendirmelere ulaşı1mıştır.

- Anket uygulanan şirketlerin \%47'si 11 ile 20 yıl arasında faaliyet gösterirken, \%30'u 10 yılın altında, \%17'si 21 ile 30 yıl arası ve \%6'sı 30 yılın üstünde faaliyet göstermektedir.

- Şirketlerin \%75'i imalat,\%23'ü ticaret ve \%2'si ise hizmet sektöründe faaliyet göstermektedir.

- Şirketlerin \%41'i tekstil, \%32'si deri, \% 7'i gida sektöründe faaliyet gösterirken \%20'si diğer farklı sektörlerde faaliyet göstermektedir.

- Şirketlerin \%60'1 mali müşavirlerinin devlet teşvikleri konusunda yeterli bilgisinin olduğunu düşünürken, \%40’1 yeterli bilgisinin olmadığını düşünmektedir.

- \%72'si 50 kişiden az çalışan istihdam etmekteyken, \%13'ü 51 ile 100 arası, \%8'i 101ile 200 kişi arası, \%7'si ise 200'ün üzerinde personel istihdam etmektedir.

- Şirket yönetiminin \%63'ü devlet teşvikleri hakkında yeterli bilgiye sahip olduklarını düşünürken, \%37'si yeterli bilgisinin olmadığını ifade etmiştir.

- Anket yapılan şirketlerin \%57'si devlet teşviklerinden yararlanırken, \%43'ü devlet teşviklerinden yararlanmamaktadır.

- Şirketlerin \%43'ü Uşak ilinde faaliyette bulunmalarında Uşak ili için verilen teşviklerin etkisi olduğunu ifade ederken \%57'si etkisinin olmadığını ifade etmiştir.

- Şirketlerin \%33’ü teşviklerin yeni yatırımlara yönelmelerinde etkili olduğunu düşünürken, \%57'si teşvikleri yeni yatırımlarda etkili görmemiştir.

- Teşviklerden yararlanmama sebepleri arasında yasal engeller (\%14.88), kredi faiz oranlarının yüksek olması $(\% 13,10)$, gerekli koşulları sağlayamama (\%11.31) ve teşvik miktarının yeterli olmaması $(\% 10,71)$ en fazla yüzdeye sahip olan nedenlerdir.

- Yararlanılan devlet teşvikleri yüzdelik sırasına göre; sigorta primi desteği, katma değer vergisi istisnası, katma değer vergisi iadesi, nitelikli eleman istihdamı desteği, vergi indirimi ve diğer teşvik çeşitleridir. 
- Şirketlerin \%72'si devlet teşviklerinin devam etmemesi durumunda teşvikten yararlandıkları yatırıma devam etmeyi düşünüyorken, \%28'i devam etmeyi düşünmemektedir.

- Şirketlerin \%37'si devlet teşviklerinden yararlanmalarında mali müşavirlerinin katkısının olduğunu belirtirken, \%12'si kısmen katkısının olduğunu, \%8'i mali müşavirin katkısının olmadığını ifade etmiştir. Diğer şirketler ise teşviklerden yararlanmadıkları için ilgili soruya cevap vermemişlerdir.

Tablo 2: Devlet Teşviklerinin Şirketler Üzerinde Etkileri

\begin{tabular}{lcccc}
\hline & Azaldı & Değişmedi & Arttı & Önemli Oranda Arttı \\
\hline İthalat & 1,61 & 50,00 & 41,94 & 6,45 \\
\hline İhracat & 0,00 & 26,15 & 67,69 & 6,15 \\
\hline Satış & 1,05 & 36,84 & 51,58 & 10,53 \\
\hline Üretim & 1,05 & 28,42 & 60,00 & 10,53 \\
\hline Ürün Çeşitliliği & 1,05 & 55,79 & 35,79 & 7,37 \\
\hline Kârılık & 2,11 & 29,47 & 57,89 & 10,53 \\
\hline Çalışan Sayısı & 0,00 & 34,74 & 52,63 & 12,63 \\
\hline Ar-Ge Harcamaları & 1,72 & 50,00 & 34,48 & 13,79 \\
\hline Yeni Ürün Geliştirme & 1,92 & 63,46 & 28,85 & 5,77 \\
\hline
\end{tabular}

Yapılan çalışmada devlet teşviklerinin şirket üzerindeki etkilerini ölçmek amacıyla şirket yetkililerine farklı sorular yöneltilmiştir. Tablo 2`de görüldüğü gibi alınan cevaplar doğrultusunda devlet teşviklerinden yararlanmanın sonucunda şirketin ihracat, satış, üretim, çalışan sayısı ve kârlılığında artış olduğunu düşünenlerin oranı \%50'nin üzerindedir. Buna karşılık cevap verenlerin $\% 50$ 'den fazlası ise ithalat, ürün çeşitliliği, Ar-Ge harcamaları ve yeni ürün geliştirmede değişiklik olmadığını ifade etmişlerdir. Genel olarak şirketlerin tüm bu unsurlarında azalma olduğunu düşünenlerin sayısı \%2'den azdır. Bazı şirket yetkilileri ise önemli oranda artış olduğunu ifade etmişlerdir.

Tablo 3: Faktörlerin Belirlenmesi

\begin{tabular}{|c|c|c|c|}
\hline & \multicolumn{3}{|c|}{ Faktör Yükleri } \\
\hline & 1 & 2 & 3 \\
\hline Kâr & .788 & .105 & .055 \\
\hline Satış & .769 & -.139 & .431 \\
\hline Üretim & .755 & -.094 & .268 \\
\hline Ürün Çeşitliliği & .628 & .404 & .008 \\
\hline Çalışan Sayısı & .531 & .444 & .045 \\
\hline Yeni Ürün Geliştirme & .063 & .928 & .144 \\
\hline Ar-ge & .014 & .883 & .198 \\
\hline İhracat & .184 & .126 & .834 \\
\hline İthalat & .139 & .220 & .810 \\
\hline
\end{tabular}

Yapılan KMO and Bartlett's Testi ile $(\mathrm{KMO}=0,71$, Bartlett faktör analizi prob $=0,000)$ verilere faktör analizi yapılmasının uygun olduğu tespit edilmiştir. Yapılan faktör analizi sonuçlarına göre gözlemlerin üç faktör tarafından temsil edildiği Tablo 4'de gösterilmiştir. Analiz sonuçlarına göre kâr, satış, üretim, ürün çeşitliliği ve çalışan sayısı değişkenleri üretim faaliyeti faktörü olarak isimlendirilmiş̧ir. Yeni ürün geliştirme ve araştırma-geliştirme değişkenleri yenilikçilik faktörü olarak, ihracat ve ithalat değişkenleri ise dış ticaret faktörü olarak isimlendirilmiştir.

Tablo 4: Faktörlerin İsimlendirilmesi

\begin{tabular}{lll}
\hline Faktör 1 & Üretim Faaliyetleri & Kâr, Satış, Üretim, Ürün Çeşitliliği, Çalışan Sayıs1 \\
\hline Faktör 2 & Yenilikçilik & Yeni Ürün Geliştirme, Araştırma-Geliştirme \\
\hline Faktör 3 & Diş Ticaret & İhracat, İthalat \\
\hline
\end{tabular}

Elde edilen faktörler kullanılarak yapılan Varyans ve Post Hoc analizi sonuçları aşağıda Tablo 5 'te gösterilmiştir. 
Tablo 5: Varyans ve Post Hoc Analizi Sonuçları

\begin{tabular}{lccc}
\hline Karşılaştırma Grubu & Üretim Faaliyetleri & Yenilikçilik & Dış Ticaret \\
\hline Faaliyet Süresi & 0,214 & 0,967 & 0,920 \\
\hline Faaliyet Alanı (Üretim, Ticaret,Hizmet) & 0,985 & 0,439 & 0,405 \\
\hline Faaliyet Alan1 & 0,590 & 0,0520 & $\mathbf{0 , 0 1 6}^{*}$ \\
\hline Çalışan Sayıs1 & $\mathbf{0 , 0 2 1}$ & 0,158 & 0,475 \\
\hline Teşvik Bilgisi & $\mathbf{0 , 0 2 9}$ & 0,398 & 0,325 \\
\hline Mali Müşavirin Katkıs1 & 0,562 & 0,475 & 0,761 \\
\hline Mali Müşavirin Bilgisi & $\mathbf{0 , 0 8 6}$ ( $^{*}$ & 0,672 & $\mathbf{0 , 0 1 8}^{*}$ \\
\hline
\end{tabular}

Tablo 5 incelendiğinde;

- Tekstil ile gıda sektörü arasında dış ticaret ortalamaları bakımından farklılık vardır.

- 1-50 kişi ile 51-100 çalıştıran şirketlerin üretim faaliyetleri ortalaması arasında anlamlı bir farklılık vardır.

- Devlet teşvikleri konusunda yeterince bilgisi olanlar ile olmayanlar arasında üretim faaliyetleri ortalaması arasında anlamlı bir farklılık vardır.

- Mali müşavirinin teşvikler konusunda yeterince bilgisinin olması ile olmamasının üretim faaliyetleri ve dış ticaret ortalamaları arasında anlamlı bir farklılık vardır.

Ayrıca yeni yatırımlara yönelmede faktörlerin etkisini ölçmek amacıyla Lojistik Regresyon Analizi yapılmıştır. Analiz sonuçlarına göre yeni yatırımlara yönelmede üretim faaliyetleri ve yenilik değişkenlerinin etkili olduğu tespit edilmiştir. Üretim faaliyetlerindeki değişimin yeni yatırımlara yönelmede 2,5 kat daha etkili olduğu belirlenmiştir.

Çalışmada ayrıca mali müşavir katkısı ve mali müşavirin devlet teşvikleri konusunda bilgisi ile satış, ihracat, üretim ve kârlılık arasında bir ilişki olup olmadığg Ki-Kare analizi ile incelenmiştir. Analiz sonucunda mali müşavirin katkısı ile kârlılık arasında ve mali müşavirin bilgisi ile satış, ihracat, üretim ve kârlılık arasında anlamlı bir ilişki tespit edilmiştir.

Tablo 6: Kârlılığın Artmasında Mali Müşavirin Katkısı

\begin{tabular}{|c|c|c|c|c|c|c|c|}
\hline & & & Azaldı & Değişmedi & Arttı & Önemli Oranda Arttı & Toplam \\
\hline \multirow{6}{*}{$\begin{array}{l}\text { Mali Müşavirin } \\
\text { Katkısı }\end{array}$} & \multirow[b]{2}{*}{ Var } & & 2 & 14 & 36 & 8 & 60 \\
\hline & & Yüzde & 3.3 & 23.4 & 60 & 13.3 & 100,0 \\
\hline & \multirow{2}{*}{ Yok } & & 0 & 9 & 4 & 1 & 14 \\
\hline & & Yüzde & 0 & 64.3 & 28.6 & 7.1 & 100,0 \\
\hline & \multirow{2}{*}{ Kismen } & & 0 & 5 & 15 & 1 & 21 \\
\hline & & Yüzde & 0 & 23.8 & 71.4 & 4.8 & 100,0 \\
\hline \multirow{2}{*}{ Toplam } & & & 2 & 28 & 55 & 10 & 95 \\
\hline & & Yüzde & 2.1 & 29.5 & 57.9 & 10.0 & 100,0 \\
\hline
\end{tabular}

Ki Kare 11,97 , prob=0,06

Tablo 6 'da görüldüğü gibi kârlılık ile mali müşavirin katkısı arasında anlamlı bir ilişki vardır (Ki Kare 11,97, prob=0.06). Mali müşavirin devlet teşviklerinden yararlanmalarında katkısının olduğunu düşünen şirketlerin \%57,9'u kârlarında artış olduğunu ifade etmiştir. Mali müşavir katkısının kâr üzerinde etkili olduğunu düşünen şirketlerin içerisinde kârlarında artış olduğunu ifade edenlerin oranı \%60, önemli oranda artış olduğunu söyleyenlerin oranı \%13,3'dür. Dolayısıyla kâr artışı sağladı diyenler toplamda \% 73,3'tür. Buna karşın müşavir katkısı olduğunu düşündükleri halde kârlığının azaldığını ifade eden şirket oranı \%3,3'tür. Şirketlerin \%23,4’ü ise kârlılığında mali müşavirin bir katkısının olmadığını ifade etmiştir. 
Tablo 7: İhracatın Artmasında Mali Müşavirin Devlet Teşviklerine İlişkin Bilgisi

\begin{tabular}{|c|c|c|c|c|c|c|}
\hline & & & Değişmedi & Arttı & Önemli Oranda Arttı & Toplam \\
\hline \multirow{4}{*}{ Mali Müşavirin Katkısı } & \multirow{2}{*}{ Var } & & 10 & 36 & 4 & 50 \\
\hline & & Yüzde & 20 & 72 & 8 & 100,0 \\
\hline & \multirow{2}{*}{ Yok } & & 7 & 8 & 0 & 15 \\
\hline & & Yüzde & 46.7 & 53.3 & 0 & 100,0 \\
\hline \multirow{2}{*}{ Toplam } & & & 17 & 44 & 4 & 65 \\
\hline & & Yüzde & 26.2 & 67.7 & 6.2 & 100,0 \\
\hline
\end{tabular}

Ki-Kare 4,93, prob=0,08

Tablo 7'de görüldüğü gibi ihracat ile mali müşavirin devlet teşviklerine ilişkin bilgisi arasında anlamlı bir ilişki vardır (Ki-Kare 4,93, prob=0,08). Analizi yapılan şirketlerin \%67,7'si ihracatlarında artış olduğunu belirtmişlerdir. Mali müşavirin devlet teşvikleri konusunda bilgisinin olduğunu düşünen şirketlerin $\% 72$ 'si ihracatlarında artış olduğunu ifade etmişlerdir. \%8'i ise önemli oranda artış olduğunu belirtmiştir. Dolayısıyla ihracat artışı sağladı diyenler toplamda \%80'dir. Buna karşın mali müşavirin bilgisi olduğunu düşündükleri halde ihracatlarının değişmediğini ifade eden şirket oranı $\% 20$ 'dir.

Tablo 8: Satışların Artmasında Mali Müşavirin Devlet Teşviklerine İlişkin Bilgisi

\begin{tabular}{|c|c|c|c|c|c|c|c|}
\hline & & & Azaldı & Değişmedi & Arttı & Önemli Oranda Arttı & Toplam \\
\hline \multirow{4}{*}{$\begin{array}{l}\text { Mali Müşavirin } \\
\text { Bilgisi }\end{array}$} & \multirow{2}{*}{ Var } & & 1 & 21 & 38 & 10 & 70 \\
\hline & & Yüzde & 1.4 & 30 & 54.3 & 14.3 & 100,0 \\
\hline & \multirow{2}{*}{ Yok } & & 0 & 14 & 11 & 0 & 25 \\
\hline & & Yüzde & 0 & 56 & 44 & 0 & 100,0 \\
\hline \multirow{2}{*}{ Toplam } & & & 1 & 35 & 49 & 10 & 95 \\
\hline & & Yüzde & 1.1 & 36.8 & 51.6 & 10.5 & 100,0 \\
\hline
\end{tabular}

Ki-Kare 7,68, prob=0,05

Tablo 8'de görüldüğü gibi satışlar ile mali müşavirin devlet teşviklerine ilişkin bilgisi arasında anlamlı bir ilişki vardır (Ki-Kare 7,68, prob=0,05). Analizi yapılan şirketlerin \%51,6'sı satışlarında artış olduğunu belirtmiş̧lerdir. Mali müşavir bilgisinin satış üzerinde etkili olduğunu düşünen şirketlerin içerisinde satışlarında artış olduğunu ifade edenlerin oran $1 \% 54,3$, önemli oranda artış olduğunu söyleyenlerin oranı \%14,3'dür. Dolayısıyla satış artışı sağladı diyenler toplamda \%68,6'dır. Buna karşın mali müşavirin bilgisinin etkisi olduğunu düşündükleri halde satışlarının azaldığını ifade eden şirket oranı \%1,4'dür. \%30'u ise satışlarında herhangi bir değişme olmadığını ifade etmiştir.

Tablo 9: Üretimin Artmasında Mali Müşavirin Devlet Teşviklerine İlişkin Bilgisi

\begin{tabular}{|c|c|c|c|c|c|c|c|}
\hline & & & Azaldı & Değişmedi & Arttı & Önemli Oranda Arttı & Toplam \\
\hline \multirow{4}{*}{ Mali Müşavirin Bilgisi } & \multirow{2}{*}{ Var } & & 1 & 15 & 44 & 10 & 70 \\
\hline & & Yüzde & 1.4 & 21.4 & 62.9 & 14.3 & 100,0 \\
\hline & \multirow{2}{*}{ Yok } & & 0 & 12 & 13 & 0 & 25 \\
\hline & & Yüzde & 0 & 48 & 52 & 0 & 100,0 \\
\hline \multirow{2}{*}{ Toplam } & & & 1 & 27 & 57 & 10 & 95 \\
\hline & & Yüzde & 1.1 & 28.4 & 60 & 10.5 & 100,0 \\
\hline
\end{tabular}

Ki-Kare 8,86, prob $=0,03$

Tablo 9'da görüldüğü gibi üretim ile mali müşavirin devlet teșviklerine ilişkin bilgisi arasında anlamlı bir ilişki vardır (Ki-Kare 8,86, prob=0,03). Analizi yapılan şirketlerüretimlerinde $\% 60$ artış olduğunu belirtmişlerdir. Mali müşavir bilgisinin üretim üzerinde etkili olduğunu düşünen şirketlerin içerisinde üretimlerinde artış olduğunu ifade edenlerin oran $\% 62,9$, önemli oranda artış olduğunu söyleyenlerin oranı \%14,3'dür. Dolayısıyla üretim artışı sağladı diyenler toplamda \%77,2'dir. Buna karşın mali müşavirin bilgisinin etkisi olduğunu düşündükleri halde üretimlerinin azaldığııı ifade eden şirket oranı \%1,1'dir. \%28,4’ü ise üretimlerinde herhangi bir değişme olmadığını ifade etmiştir. 
Tablo 10: Kârlılığın Artmasında Mali Müşavirin Devlet Teşviklerine İlişkin Bilgisi

\begin{tabular}{|c|c|c|c|c|c|c|c|}
\hline & & & Azaldı & Değişmedi & Arttı & Önemli Oranda Arttı & Toplam \\
\hline \multirow{4}{*}{ Mali Müşavirin Bilgisi } & \multirow{2}{*}{ Var } & & 2 & 15 & 45 & 8 & 70 \\
\hline & & Yüzde & 2.9 & 21.4 & 64.3 & 11.4 & 100,0 \\
\hline & \multirow{2}{*}{ Yok } & & 0 & 13 & 10 & 2 & 25 \\
\hline & & Yüzde & 0 & 52 & 40 & 8 & 100,0 \\
\hline \multirow{2}{*}{ Toplam } & & & 2 & 28 & 55 & 10 & 95 \\
\hline & & Yüzde & 2.1 & 29.5 & 57.9 & 10.5 & 100,0 \\
\hline
\end{tabular}

Ki -Kare 8,63, prob=0,03

Tablo10'da görüldüğü gibi kârlılık ile mali müşavirin bilgisi arasında anlamlı bir ilişki vardır (Ki-Kare 8,63, prob=0,03). Analizi yapılan şirketlerin \%57,9'u kârlarında artış olduğunu ifade etmiştir. Müşavir bilgisinin kar üzerinde etkili olduğunu düşünen şirketlerin içerisinde kârlarında artış olduğunu ifade edenlerin oran $1 \% 64,3$ önemli oranda artış olduğunu söyleyenlerin oran $1 \% 11,4$ 'dür. Dolayısıyla kar artışı sağladı diyenler toplamda \%75,7'dir. Buna karşın müşavir bilgisinin etkisi olduğunu düşündükleri halde kârlarının azaldığını ifade eden şirket oranı $\% 2,9^{\prime}$ dur. \%21,4'ü ise kârlarında herhangi bir değişme olmadığını ifade etmiştir.

\section{SONUÇ}

İşletmeler yeni yatırımlara yönelmek, mevcut işletmelerini büyütmek, üretim, istihdam ve araştırma-geliştirme faaliyetlerini artırmak yeni ürün geliştirmek gibi amaçlarla devlet teşviklerinden yararlanırlar. Devletler de bu konularda işletmeleri desteklemek ve özendirmek için devlet teşviki verirler. Ülkemizde 2009 yılında yayımlanan "Yatırımlarda Devlet Yardımları Hakkında Bakanlar Kurulu Kararı" ile devlet teşvikleri düzenlenmiştir. Yıllar içerisinde birçok kez bu kararda değişiklik yapılmasına ilişkin kararlar yayımlanmıştır. Devlet yardımlarına ilişkin en son 21 Ağustos 2020 tarih ve 31220 sayılı "Yatırımlarda Devlet Yardımları Hakkında Kararda Değişiklik Yapılmasına İlişskin Karar" Resmi Gazetede yayımlanmıştır. Bu kararda illerin hangi teşvik bölgelerinde olduğu belirlenmiş, bölgesel desteklerden faydalanabilecek sektörler, bölgeler itibariyle asgari yatırım tutarları ve kapasiteleri ve teşviklerden yararlanacak yatırım konuları açıklanmıştır.

Türkiye'de devlet teşviklerinin verilmesinde 6 teşvik bölgesi belirlenmiştir. Her bölge devlet teşviklerinden bölgesel özelliklerine göre yararlanırlar. Ülkemizde verilen genel devlet teşvikleri Katma Değer Vergisi İstisnası ve Gümrük Vergisi Muafiyetidir. Vergi İndirimi, Sigorta Primi İşveren Hissesi Desteği, Sigorta Primi Desteği, Gelir Vergisi Stopajı Desteği, Faiz Veya Kar Payı Desteği, Yatırım Yeri Desteği, Katma Değer Vergisi İadesi ise bölgesel teşviklerdir.

Bu çalışmada Yatırım Teşvik Uygulamalarında 3. Bölgede yer alan Uşak'ta faaliyet gösteren şirketlerin devlet teşviklerinden yararlanma eğilimlerinin saptanmış ve söz konusu şirketlerin devlet teşviklerine yönelmelerinde serbest muhasebeci mali müşavirlerinin katkısı ölçülmüştür. Ayrıca mali müşavirin devlet teşvikleri konusunda bilgili olmasıyla şirket satışları, ihracatı, üretimi ve karlılığı arasındaki ilişki analiz edilmiştir.

Çalışmada Uşak'ta faaliyet gösteren 168 şirkete yüz yüze anket uygulanmıştır. Bu şirketlerin \%75'i imalat, \%23'ü ticaret ve \%2'si ise hizmet işletmesidir. Şirketlerin \%41'i tekstil, \%32'si deri, \%7'si gıda sektöründe faaliyet gösterirken \%20'si diğer farklı sektörlerde faaliyet göstermektedir. Anket yapılan şirketlerin \%57'si devlet teşviklerinden yararlanırken, \%43'ü devlet teşviklerinden yararlanmamaktadır. Şirketlerin \%33'ü teşviklerin yeni yatırımlara yönelmelerinde etkili olduğunu düşünürken, \%57'si teşvikleri yeni yatırımlarda etkili görmemiştir. Teşviklerden yararlanmama sebepleri arasında yasal engeller (\%14.88), kredi faiz oranlarının yüksek olması $(\% 13,10)$, gerekli koşulları sağlayamama (\%11.31) ve teşvik miktarının yeterli olmaması $(10,71)$ en fazla yüzdeye sahip olan nedenlerdir. Yararlanılan devlet teşvikleri yüzdelik sırasına göre; sigorta primi desteği, katma değer vergisi istisnası, katma değer vergisi iadesi, nitelikli eleman istihdamı desteği, vergi indirimi ve diğer teşvik çeşitleridir.

Muhasebe meslek mensupları mali uygulamalar konusunda işletmelere danışmanlık yaparlar. Devlet teşvikleri konusunda da işletmelere bilgi verirler. Yapılan çalışmaya katılan şirketlerin \%60'1 mali müşavirlerinin devlet teşvikleri konusunda yeterli bilgisinin olduğunu düşünürken, \%40'1 yeterli bilgisinin olmadığını düşünmektedir. Şirketlerin \%36'sı devlet teşviklerinden yararlanmalarında mali 
müşavirlerinin katkıs1 olduğunu düşünürken, $\% 8$ 'i mali müşavirlerinin katkısı olmadığını ifade etmiştir. \%12,5 kısmen katkılarının olduğunu düşünürken \% 43,5'i bu soruyu cevapsız bırakmıştır.

Anket verilerine faktör analizi uygulanmıştır. Faktör analizi sonucu elde edilen faktörlere uygulanan Varyans analizi sonuçlarına göre tekstil ile gıda sektörü arasında dış ticaret ortalamaları bakımından farklılık vardır. 1-50 kişi ile 51-100 çalıştıran şirketlerin üretim faaliyetleri ortalaması arasında anlamlı bir farklılık vardır. Ayrıca devlet teşvikleri konusunda yeterince bilgisi olanlar ile olmayanlar arasında üretim faaliyetleri ortalaması arasında anlamlı bir farklılı̆̆ın olduğu; mali müşavirinin teşvikler konusunda yeterince bilgisi olanlar ile olmayanların üretim faaliyetleri ve dış ticaret ortalamaları arasında anlamlı bir farklılığın olduğu; mali müşavirinin teşvikler konusunda yeterince bilgisinin olması ile olmamasının üretim faaliyetleri ve dış ticaret ortalamaları arasında anlamlı bir farklılığın olduğu tespit edilmiştir.

Ayrıca yeni yatırımlara yönelmede faktörlerin etkisini ölçmek amacıyla Lojistik Regresyon Analizi yapılmıştır. Analiz sonuçlarına göre yeni yatırımlara yönelmede üretim faaliyetleri ve yenilik değişkenlerinin etkili olduğu tespit edilmiştir. Üretim faaliyetlerindeki değişimin yeni yatırımlara yönelmede 2,5 kat daha etkili olduğu belirlenmiştir.

Çalışmanın son bölümünde mali müşavir katkısı ve mali müşavirin devlet teşvikleri konusunda bilgisi ile satış, ihracat, üretim ve kârlılık arasında bir ilişki olup olmadığg Ki-Kare analizi ile incelenmiştir. Analiz sonucunda mali müşavirin katkısı ile kârlılık arasında ve mali müşavirin bilgisi ile satış, ihracat, üretim ve kârlılık arasında anlamlı bir ilişki tespit edilmiştir.

Mali müşavirin devlet teşviklerinden yararlanmalarında katkısının olduğunu düşünen şirketlerin \%57,9'u kârlarında artış olduğunu ifade etmiş̧ir. Mali müşavir katkısının kâr üzerinde etkili olduğunu düşünen şirketlerin içerisinde kâr artışı sağladı diyenler toplamda \%73,3'dür. Buna karşın müşavir katkısı olduğunu düşündükleri halde kârlığının azaldığını ifade eden şirket oranı \%3,3'dür. Şirketlerin \%23,4’ü ise kârlılığında mali müşavirin bir katkısının olmadığını ifade etmiştir

Analizi yapılan şirketlerin \%67,7'si ihracatlarında artış olduğunu belirtmişlerdir. Mali müşavirin devlet teşvikleri konusunda bilgisinin olduğunu düşünen şirketlerin toplamda \%80'i ihracatlarında artış olduğunu ifade etmişlerdir. Buna karşın mali müşavirin bilgisi olduğunu düşündükleri halde ihracatlarının değişmediğini ifade eden şirket oranı \%20'dir.

Analize yanıt veren şirketlerin \%51,6'sı satışlarında artış olduğunu belirtmişlerdir. Mali müşavir bilgisinin satış üzerinde etkili olduğunu düşünen şirketlerin içerisinde satışlarında artış olduğunu ifade edenlerin oranı \%68,6'dır Buna karşın mali müşavirin bilgisinin etkisi olduğunu düşündükleri halde satışlarını azaldığını ifade eden şirketlerin oranı \%1,4'dür. \%30'u ise satışlarında herhangi bir değişme olmadı̆̆ını ifade etmiştir.

Analizi yapılan şirketler üretimlerinde $\% 60$ artış olduğunu belirtmişlerdir. Mali müşavir bilgisinin üretim üzerinde etkili olduğunu düşünen şirketlerin içerisinde üretimlerinde artış olduğunu ifade edenlerin oran $\% 77,2^{\prime}$ dir. Mali müşavirin bilgisinin etkisi olduğunu düşündükleri halde üretimlerinin azaldığını ifade eden şirket oranı \%1,1 ve üretimlerinde herhangi bir değişme olmadığını ifade edenlerin oranı ise $\% 28,4$ 'dür.

Şirketlerin \%57,9'u kârlarında artış olduğunu ifade etmiştir. Müşavir bilgisinin kar üzerinde etkili olduğunu düşünen şirketlerin içerisinde kârlarında artış olduğunu ifade edenlerin toplam oranı \%75,7'dir. Müşavir bilgisinin etkisi olduğunu düşündükleri halde kârlarının azaldığını ifade eden şirket oranı \%2,9 ve kârlarında herhangi bir değişme olmadığını ifade edenlerin oranı ise \%21,4'dür.

Devlet teşviklerinin işletmelerin mevcut üretim kapasitelerini, fiziki imkânlarını, istihdam ve ürün çeşitliliğinin artırması ve yatırımlara yönelmesi üzerindeki katkıları tartışılmaz bir konudur. Muhasebe meslek mensupları da bu konuda işletme yönetimine bilgisi ve yararlanma konusundaki deneyimleri ile katkı sağlar. Devlet teşvikleri konusunda mali müşavirlerinden destek alan işletmelerin üretim, satış, dış ticaret ve kârlılıklarının daha da artıracağını söylemek mümkündür. 
Etik Beyan: Bu çalışmada kullanılan anket yöntemi için Uşak Üniversitesi Etik Kurulu'ndan 09/03/2021 tarihli ve 03 nolu toplantısinda 2021-43 sıra sayıl karart ile izin alınmıştır. Aksi bir durumun tespiti halinde AKAD Dergisinin hiçbir sorumluluğu olmayıp, tüm sorumluluk çalışmanın yazar (lar) ina aittir.

Yazar Katkı Beyant:1. Yazarın katkı oranı \%50, 2. Yazarın katkı oranı ise \%50'dir. Çıkar Beyant: Yazarlar arasında çıkar çatışması yoktur.

Ethics Statement: Permission for this study was obtained from the Ethics Committee of Uşak University with the decision number 2021-43 at the meeting dated 09/03/2021 and numbered 03 of the relevant board. In case of detection of a contrary situation, AKAD Journal has no responsibility and all responsibility belongs to the author $(s)$ of the study.

Author Contributions Statement: 1st author's contribution rate 50\%, 2nd author's contribution rate $50 \%$.

Conflict of Interest: There is no conflict of interest among the authors.

\section{KAYNAKÇA}

Akdoğan, M. U. (2011). Türkiye coğrafyasında uygulanan devlet teşvikleri ve devlet yardımlarının, uluslararası muhasebe standartları çerçevesinde analizi. Muhasebe Bilim Dünyası, 13(4), 259281. https://dergipark.org.tr/tr/pub/bartiniibf/issue/45598/489903

Altınkaynak, F., \& Doğan, Ö. (2020). Türkiye'deki finansal raporlama çerçevelerine göre devlet teşviklerinin karş1laştırmalı analizi: Turizm sektörü örneği. Muhasebe ve Finansman Dergisi, (86), 79-96. https://doi.org/10.25095/mufad.710228

Özbek, A. (2017). Devlet teşvikleri ve hazır giyim işletmeleri üzerine bir çalışma. Doğu Anadolu Sosyal Bilimlerde Eğilimler $\quad$ Dergisi, $\quad 1(1), \quad 1-14$. https://dergipark.org.tr/tr/pub/dased/issue/28623/279651

Özer, E. Y. (2015). Turizm sektöründeki teşviklerin TMS-20 Çerçevesinde muhasebeleştirilmesi ve Mardin iline yönelik bir araştırma. [Yayınlanmamış Yüksek Lisans Tezi, Balıkesir

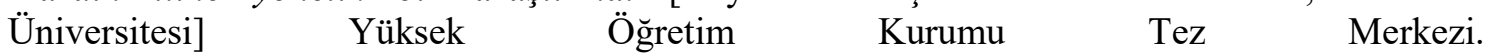
https://tez.yok.gov.tr/UlusalTezMerkezi/tezSorguSonucYeni.jsp

Sarıhan, A. Y., İncaz, S., \& Yaprak, B. (2017). Devlet teşviklerinin firmaların ihracat performansına etkisi: İstanbul ihracatçıları örneği. Atatürk Üniversitesi İktisadi ve İdari Bilimler Dergisi, 31(3), 755-774.

Tekşen, Ö. (2010). TMS 20 standardındaki devlet teşvikleri ile Türkiye'de yeni teşvik sisteminde yatırıma sağlanan desteklerin muhasebe ve vergi açısından incelenmesi. Marmara Üniversitesi İ.I.B.F. Dergisi, XXIX(II), 431-453. https://dergipark.org.tr/tr/pub/muiibd/issue/487/4527

Temelli, F. (2019). Tarımsal faaliyetlere yönelik devlet teşviklerinin Türkiye muhasebe standartları çerçevesinde muhasebeleştirilmesi. Bartın Üniversitesi İktisadi ve İdari Bilimler Fakültesi Dergisi, 10(19), 1-18. https://dergipark.org.tr/tr/pub/bartiniibf/issue/45598/489903

TURMOB (Türkiye Serbest Muhasebeci Mali Müşavirler ve Yeminli Mali Müşavirler Odaları Birliği). (1989). 3568 sayıl serbest muhasebeci mali müşavirlik ve yeminli mali müşavirlik kanunu. https://www.turmob.org.tr/Mevzuat/8/3568-sayili-kanun

Ulusal Müşavirlik Danışmanlı ve Çözümleri. Teşvik bölgeleri ve teşvik destek unsurları, https://dengemusavirlik.com/2013-yatirim-tesvik-sistemi.htm

Yakupçebioğlu, H. (2016). Kentsel dönüşüm kapsamında yapılan inşaatların yapılış biçimleri. Devlet yardımları, teşvikleri, muafiyetler, vergi ve muhasebe uygulamaları. Mali Çözüm Dergisi, 136, 251-265. http://archive.ismmmo.org.tr/docs/malicozum/136malicozum/19.pdf

Yatırımlarda devlet yardımları hakkında karar. (2009, 16 Temmuz). T.C. Resmî Gazete (Sayı: 27290), Bakanlar Kurulu Karar1. https://www.resmigazete.gov.tr/eskiler/2009/07/20090716-5.htm

Yıldız, F., Topal Y., \& Küçükkahraman, B. (2012). Sanayi işletmelerine verilen teşviklerin "TMS 20: Devlet teşviklerinin muhasebeleştirilmesi ve devlet yardımlarının açıklanması standardı" 
1şı̆̆ında incelenmesi ve muhasebeleştirilmesi. Afyon Kocatepe Üniversitesi İ̈BF Dergisi, XIV(I), 295-312. https://dergipark.org.tr/tr/pub/idusos/issue/55641/714247

Yürütme ve idare bölümü milletlerarası andlaşma. (2020, 21 Ağustos). T.C. Resmî Gazete (Say1: 31220). https://www.resmigazete.gov.tr/21.08.2020

Zhang, J. \& Guan, J. (2018). The time-varying impacts of government incentives on innovation. Technological Forecasting and Social Change, 135, 132-144. https://doi.org/10.1016/j.techfore.2018.04.012 